\title{
Cardioprotective Properties of Opioid Receptor Agonists in Rats With Stress-Induced Cardiac Injury
}

\author{
E. S. PROKUDINA ${ }^{1}$, L. N. MASLOV ${ }^{1}$, N. V. NARYZHNAYA ${ }^{1}$, S. YU. TSIBULNIKOV ${ }^{1}$, \\ Y. B. LISHMANOV ${ }^{1,2}$, J. E. MADIAS ${ }^{3}$, P. R. OELTGEN ${ }^{4}$
}

${ }^{1}$ Laboratory of Experimental Cardiology, Cardiology Research Institute, Tomsk National Research Medical Center, Russian Academy of Sciences, Tomsk, Russia, ${ }^{2}$ Laboratory of Nuclear Medicine, National Research Tomsk Polytechnic University, Tomsk, Russia, ${ }^{3}$ Icahn School of Medicine at Mount Sinai and the Division of Cardiology, Elmhurst Hospital Center, New York, New York, USA, ${ }^{4}$ Department of Pathology, University of Kentucky College of Medicine, Lexington, KY, USA

Received May 22, 2018

Accepted December 4, 2018

Epub Ahead of Print March 22, 2019

\begin{abstract}
Summary
The objectives of this study were to investigate the role of endogenous opioids in the mediation of stress-induced cardiomyopathy (SIC), and to evaluate which opioid receptors regulate heart resistance to immobilization stress. Wistar rats were subjected to $24 \mathrm{~h}$ immobilization stress. Stress-induced heart injury was assessed by ${ }^{99 \mathrm{~m}} \mathrm{Tc}$-pyrophosphate accumulation in the heart. The opioid receptor (OR) antagonists (naltrexone, NXMB - naltrexone methyl bromide, MR 2266, ICI 174.864) and agonists (DALDA, DAMGO, DSLET, U-50,488) were administered intraperitoneally prior to immobilization and $12 \mathrm{~h}$ after the start of stress. In addition, the selective $\mu$ OR agonists PL017 and DAMGO were administered intracerebroventricularly prior to stress. Finally pretreatment with guanethidine was used. Naltrexone did not alter the cardiac ${ }^{99 \mathrm{~m}} \mathrm{Tc}$-PP accumulation in stressed rats. NxMB aggravated stress-induced cardiomyopathy $(P=0.005)(S I C)$. The selective $\mu$ OR agonist DALDA, which does not cross the blood-brain barrier, completely prevented $(P=0.006)$ SIC. The $\mu$ OR agonist DAMGO exhibited weaker effect than DALDA. The selective $\delta$ ligand (DSLET) and $\kappa$ OR ligand (U-50,488) did not alter stress-induced ${ }^{99 \mathrm{~m}} \mathrm{Tc}$-pyrophosphate accumulation in the heart. Intracerebroventricular administration of the $\mu \mathrm{OR}$ agonists aggravated SIC. Pretreatment with guanethidine abolished this effect $(P=0.01)$. Guanethidine alone exhibited cardioprotective properties. A stimulation of central $\mu$ OR promotes an appearance of SIC. In contrast, stimulation of
\end{abstract}

peripheral $\mu \mathrm{OR}$ contributes to an increase in cardiac tolerance to stress.

\section{Key words}

${ }^{99 m}$ Tc-pyrophosphate • Opioid receptors • Tako-tsubo syndrome • Stress $\bullet$ Cardiomyopathy

\section{Corresponding author}

L. N. Maslov, Laboratory of Experimental Cardiology, Federal State Budgetary Scientific Institution «Research Institute for Cardiology, Kyevskaya 111A, 634012 Tomsk, Russia. E-mail: maslov@cardio-tomsk.ru

\section{Introduction}

In the mid-seventies of the last century it was found that restraint stress could cause cardiomyopathy in pigs (Jönsson et al. 1975, Johansson et al. 1974), and food-shock stress could induce cardiomyopathy in rats (Miller and Mallov 1977). In 1990, stress-induced cardiomyopathy was described in humans by Sato et al. (1990). These authors called the condition tako-tsubo syndrome (TS) because the left ventricle of patients afflicted with this pathology during systole resembles the Japanese octopus fishing implement called "tako-tsubo" (Sato et al. 1990). Later, the existence of the disease was confirmed by other cardiologists (Pavin et al. 1997, 
Tsuchihashi et al. 2001, Kurisu et al. 2003, Akashi et al. 2003). The incidence of TS was found to be increased as a result of improved diagnostic methods. According to Khera et al. (2016) from 2007 to 2012, the incidence of TS increased over 3-fold in the United States, as reflected in the relevant literature. Thus, in 2007, there were 52 cases per 1 million, and in 2012 already 178 cases per million hospitalized patients were reported (Khera et al. 2016). The rate of 28-day mortality in patients with TS is similar to mortality in patients with ST-segment elevation myocardial infarction (STEMI) $(5.5 \%$ vs. $5.7 \%)$ (Stiermaier et al. 2016), while the rate of 1-year mortality in patients with TS and in patients with STEMI is $12.5 \%$ vs. $9 \%$, respectively. The long-term mortality (during $3.8 \pm 2.5$ years) in patients with TS was significantly higher compared to the one of STEMI patients ( $24.7 \%$ vs. $15.1 \%$ ) (Stiermaier et al. 2016). In-hospital mortality in the TS patients with cardiopulmonary failure is $18 \%$ (El-Battrawy et al. 2017). This high mortality may be partially due to limitations of our knowledge about the pathogenesis of the disease, and as a result to the lack of a specific effective therapy of TS. In our opinion, animal studies could contribute important insights in the pathogenesis and management of TS.

Immobilization stress in rats has been found to promote the development of a state similar to TS (Ueyama et al. 2002, Ueyama et al. 2004). Although researchers have been studying TS already for the past 26 years, the pathogenesis of this disease remains a mystery in many ways. Currently, the focus is on activation of the adrenergic system in the pathogenesis of stress-induced cardiomyopathy (Chen et al. 2017, Dilsizian et al. 2017, Pelliccia et al. 2017, Sestini et al. 2017, Casey et al. 2017, Kido et al. 2017, Ceccacci et al. 2016, Chen et al. 2016, Christensen et al. 2016). Exogenous catecholamines can cause the TS (Casey et al. 2017, Kido et al. 2017, Elikowski et al. 2017, Nazir et al. 2017, Belliveau et al. 2016). Stress-induced cardiomyopathy (SIC) is often noted in patients with pheochromocytoma (Elikowski et al. 2017, Agrawal et al. 2017, Zhang et al. 2017, Y-Hassan et al. 2016). It is believed that SIC is an excessive activation of $\beta$-adrenergic receptors (Chen et al. 2017, Oras et al. 2017a, Oras et al. 2017b, Brunetti et al. 2016), so some authors mimic SIC by administration of toxic doses of isoproterenol (Oras et al. 2017a, Oras et al. 2017b, Sachdeva et al. 2014). This approach seems to us not quite correct, because in the case of using isoproterenol, other humoral factors that may be involved in the mechanism of SIC origin are not considered. Many people find themselves in severe stressful situations but TS does not occur. We hypothesize that the endogenous peripheral opioid system plays a significant role in providing a deterrent mechanism to block TS from developing. We have previously shown that the 24-hour immobilization stress can cause accumulation of ${ }^{99 \mathrm{~m}} \mathrm{Tc}$-pyrophosphate in rat myocardium (Lishmanov et al. 1997) that according to Miller and Mallov (1977) is an indicator of stress-induced myocardial injury. According to our data the ligands of opioid receptors can modulate stress heart damage (Lishmanov et al. 1997). The objectives of this study were to investigate the role of endogenous opioids in the mediation of stress-induced cardiomyopathy, and to evaluate which opioid receptors regulate heart resistance to immobilization stress.

\section{Materials and Methods}

\section{Animals and research protocol}

Male Wistar rats weighing 230-250 g were housed in groups of four rats per cage and allowed free access to tap water and a standard laboratory rat chow. Animals were kept in an air-conditioned room, where the temperature was maintained at $23 \pm 1{ }^{\circ} \mathrm{C}$, and the relative humidity was kept at $60-70 \%$. Animals were exposed to a $12 \mathrm{~h}$ day-night cycle.

Stress was induced by a 24 -hour immobilization of animals in the supine position. The rats were fixed with adhesive tape for each limb thus reducing trauma related to the procedure. Naiive rats were used as control animals. They were not supplied with water and chow during immobilization stress. Animals were immobilized and injected intraperitoneally two times with a solution of $0.9 \% \mathrm{NaCl}(1 \mathrm{ml} / \mathrm{kg})$ and were used as stress control. The first injection was administered at $9.00 \mathrm{a} . \mathrm{m}$. and the second injection at 21.00 p.m. The study was approved by the Ethical Committee of the Cardiology Research Institute (approval number: 79, from 14.10.2016), and it conformed to the European Union Directive 2010/63/EU.

In most experiments, ligands of opioid receptors (OR) were administered intraperitoneally twice: $30 \mathrm{~min}$ before immobilization and $12 \mathrm{~h}$ after the start of exposure to the stress (Lishmanov et al. 1997). In addition $\mu$ OR agonists were administered intracerebroventricularly via a cannula implanted in advance. The preferential $\mu$ and $\kappa$ OR antagonist naltrexone was administered at a dose of $0.5 \mathrm{mg} / \mathrm{kg} \quad(\mathrm{n}=12)$ (Thomas et al. 1998). Naltrexone methyl bromide (NxMB), an OR antagonist that does not 
cross the blood-brain barrier (BBB), was used at a dose of $5 \mathrm{mg} / \mathrm{kg}(\mathrm{n}=12)$ (Browen et al. 1983). The half-life of methylnaltrexone in the blood plasma is $7.6 \mathrm{~h}$ (Misra et al. 1987) and the half-life of naltrexone in various mammalian species is from 4 to $10 \mathrm{~h}$ (Crabtree 1984). Therefore, these drugs are capable of providing long-term blockade of opioid receptors. A preferential $\kappa \mathrm{OR}$ antagonist MR2266 ((-)2-(3-furyl methyl)-5,9-diethyl-2hydroxy-6,7-benzomorphan) (Lahti et al. 1985) was administered at a dose of $5 \mathrm{mg} / \mathrm{kg}(\mathrm{n}=12)$. The selective $\delta$ OR antagonist ICI 174.864 (N, N-dially-Tyr-Aib-AibPhe-Leu-OH, where the Aib is $\alpha$-aminoisobutyric acid) was administered at a dose of $2.5 \mathrm{mg} / \mathrm{kg}(\mathrm{n}=12)$ (Dauge et al. 1988, Rebrova et al. 2001). The selective $\mu \mathrm{OR}$ agonist that does not cross the BBB DALDA (H-Tyr-DArg-Phe-Lys-NH$H_{2}$ ) (Roques et al. 1990, Samii et al. 1994) was given at a dose of $0.1 \mathrm{mg} / \mathrm{kg}(\mathrm{n}=12)$ (Rebrova et al. 2001, Maslov et al. 2002). The selective $\mu \mathrm{OR}$ agonist DAMGO (H-Tyr-D-Ala-Gly-N $\alpha-M e-P h e-G l y-o l)$ 20 was injected at a dose of $0.1 \mathrm{mg} / \mathrm{kg}(\mathrm{n}=12)$ (Rebrova et al. 2001). The selective $\delta$ OR agonist DSLET (H-TyrD-Ser-Gly-Phe-Leu-Thr-OH) 20 was administered at a dose of $0.1 \mathrm{mg} / \mathrm{kg}(\mathrm{n}=12)$ (Rebrova et al. 2001). The selective $\kappa_{1}$ OR agonist $( \pm)-\mathrm{U}-50,488$ (trans- $( \pm)-3,4-$ Dichloro- $N$-methyl- $N$-[2-(1-pyrrolidinyl)cyclohexyl] benzeneacetamide hydrochloride) (Lahti et al. 1985, Von Voigtlander et al. 1982) was used at a dose of $8 \mathrm{mg} / \mathrm{kg}(\mathrm{n}=12)$ (Von Voigtlander et al. 1982).

In addition, DAMGO was administered intracerebroventricularly and the selective $\mu \mathrm{OR}$ agonist

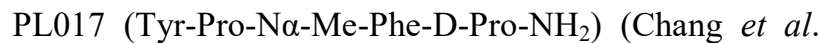
1983) was infused intracerebroventricularly both at a dose of $20 \mu \mathrm{g}$ two times: 30 min before immobilization and $12 \mathrm{~h}$ after immobilization (Chang et al. 1983). Guanethidine monosulfate, a compound which depletes peripheral storage of endogenous catecholamines (Maitre et al. 1971), was used at a dose of $50 \mathrm{mg} / \mathrm{kg}$ subcutaneously every day during 3 days (Maslov et al. 2009). The last injection of guanethidine was performed $24 \mathrm{~h}$ before immobilization. Each group included 12 animals. A total of 432 rats were included in the study. Control (naive) group included 96 animals.

\section{Measurement of ${ }^{99 m}$ Tc-pyrophosphate accumulation}

The evaluation of the extent of the stressinduced cardiac damage was studied by the assessment of the level of myocardial accumulation of radioactive ${ }^{99 \mathrm{~m}}$ Tc-pyrophosphate $\left({ }^{99 \mathrm{~m}} \mathrm{Tc}-\mathrm{PP}\right)$, which was administered intravenously in a dose of $150 \mathrm{MBq} / \mathrm{kg} 30 \mathrm{~min}$ after cessation of immobilization (Miller and Mallov 1977). The animals were decapitated under ethyl ether anesthesia $100 \mathrm{~min}$ after the injection. Hearts were removed from thorax and perfused through aorta with cold physiological saline $\left(10 \mathrm{ml}, 10{ }^{\circ} \mathrm{C}\right)$. Registration of radioactivity was measured by the $\gamma$ counter RIS-A1-E "Doscalibrator" Amplitude Company, (Third Zapadnyi 15, Zelenograd, Moscow, Russia. The accumulation of ${ }^{99 \mathrm{~m}}$ Tc-PP in the myocardial tissue was expressed as a percent of administered dose per $1 \mathrm{~g}$ of heart tissue as $\%$ of total dose/g weight of heart x 100 .

\section{Surgical procedure}

The cannula implantation was performed as described previously (Lishmanov et al. 2009). Five to 7 days before the induction of stress, a cannula, consisting of a 30 gauge stainless steel needle (SFM Hospital Products, Berlin, Germany), was inserted into the lateral cerebral ventricle of rats and was fixed in the skull by dental cement. This procedure was undertaken in surgery and in experimental procedures under pentobarbital anesthesia $(50 \mathrm{mg} / \mathrm{kg})$, and was facilitated by the use of a stereotaxic apparatus (SEZh-5; Constructor Company, Acadimika Bogomoltsa 4, Kiev, Ukraine). The cannula was inserted at the following coordinates from the bregma: AP $-1.5 \mathrm{~mm},+2.0 \mathrm{~mm}$; $\mathrm{V}-3.5 \mathrm{~mm}$. The place of injection in the lateral cerebral ventricle was confirmed by injecting methylene blue dye through the cannula at the end of the experiment. At the end of the experiment, the brain was removed, placed in formalin and later sectioned. Correct placement of the cannula was confirmed by the presence of dye in the cerebroventricular system in all rats.

\section{Pharmacological agents}

Naltrexone, U-50,488 were purchased from Sigma-Aldrich (USA). Naltrexone methyl bromide and MR2266 were synthesized by Boehringer Ingelheim KG (Ingelheim am Rhein, Germany). Peptides ICI 174.864, DAMGO, DSLET, PL017 were synthesized by Chiron Mimotopes Peptide Systems (San Diego, USA). Peptide DALDA was synthesized by Laboratory of Chemical Biology and Peptide Research, Clinical Research Institute of Montreal, Montreal, Quebec, Canada. Guanethidine was synthesized by the International Laboratory (San Bruno, CA, USA) and purchased from Advanced Technology and Industrial Co. (Hong Kong, China). 


\section{Statistical analysis}

Results are expressed as mean \pm SEM from indicated number of experiments. Statistical comparison of means between groups was made by one-way ANOVA. The assumption of normality distribution data has been tested by Shapiro-Wilk (SW) normality test. Values exceeding the $95 \%$ probability limits $(\mathrm{P}<0.05)$ were considered significant.

\section{Results}

As shown in Figure 1, immobilization stress caused an increase in the ${ }^{99 \mathrm{~m}} \mathrm{Tc}-\mathrm{PP}$ accumulation in the myocardium by 1.5 fold $(\mathrm{P}=0.001)(\sim 50 \%)$. Pretreatment with naltrexone did not alter the cardiac ${ }^{99 \mathrm{~m}} \mathrm{Tc}-\mathrm{PP}$ accumulation in stressed rats (Fig. 1). On the contrary, injection of NxMB contributed to an increase in stressevoked ${ }^{99 \mathrm{~m}}$ Tc-PP uptake by the heart $(\mathrm{P}=0.005)$ (Fig. 1$)$. It should be noted that the administration of naltrexone or NxMB had no effect on the accumulation of ${ }^{99 m}$ Tc-PP in the myocardium of naïve rats (Fig. 1). Pretreatment with DALDA caused a decrease in the stress-induced accumulation of ${ }^{99 \mathrm{~m}} \mathrm{Tc}-\mathrm{PP}$ in the myocardium by 1.8 fold $(\mathrm{P}=0.006)$ (Fig. 2a). The selective $\mu$ OR agonist DAMGO resulted in a weaker similar effect, reducing the stress induced ${ }^{99 \mathrm{~m}}$ Tc-PP heart uptake only by 1.36 fold $(\mathrm{P}=0.01)$ (Fig. 2a). The selective $\mu$ OR agonists had no effect on cardiac $99 \mathrm{mTc}-\mathrm{PP}$ accumulation in naïve rats. In contrast, intracerebroventricular administration of DAMGO and PL017 enhanced the 99mTc-PP accumulation in the heart after immobilization ( $\mathrm{P}=0.01)$ (Fig. 2b). It should be noted that the intracerebroventricular administration of selective $\mu$ OR agonists had no effect on the cardiac ${ }^{99 \mathrm{~m}}$ Tc-PP accumulation in naïve rats. As shown in Figure 3, the selective $\delta$ OR antagonist ICI 174.864 and the preferential $\kappa$ OR antagonist MR2266 did not alter the cardiac ${ }^{99 \mathrm{~m}}$ Tc-PP accumulation in naïve and stressed rats. Also the selective $\delta$ OR agonist DSLET and the selective $\kappa$ OR agonist U-50,488 had no effect on the ${ }^{99 m}$ Tc-PP uptake by the heart in both groups of animals (Fig. 4). Pretreatment with guanethidine contributed to a decrease in the cardiac ${ }^{99 \mathrm{~m}} \mathrm{Tc}-\mathrm{PP}$ accumulation in stressed rats, compared with stress control group, and attenuated intracerebroventricular DAMGO-induced ${ }^{99 \mathrm{~m}} \mathrm{Tc}-\mathrm{PP}$ accumulation in stressed rats $(\mathrm{P}=0.01)$ (Fig. 5). Finally, guanethidine did not change the cardiac ${ }^{99 \mathrm{~m}} \mathrm{Tc}-\mathrm{PP}$ accumulation in naïve rats.

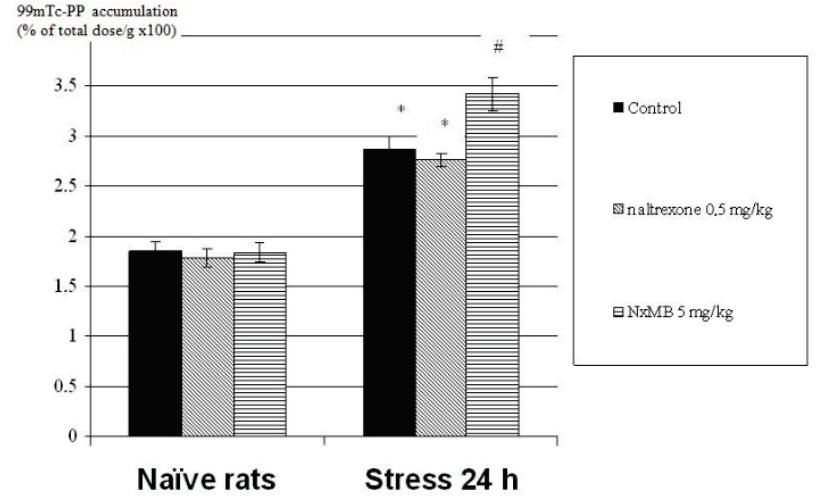

Fig. 1. Effect of the administration of 2 non-selective opioid receptor antagonists on the immobilization stress induced myocardial injury measured by the level of accumulation of ${ }^{99 \mathrm{~m}} \mathrm{Tc}$ pyrophosphate. $*$ Significant difference in comparison with naïve animals. " Significant differences compared to control stress.

a

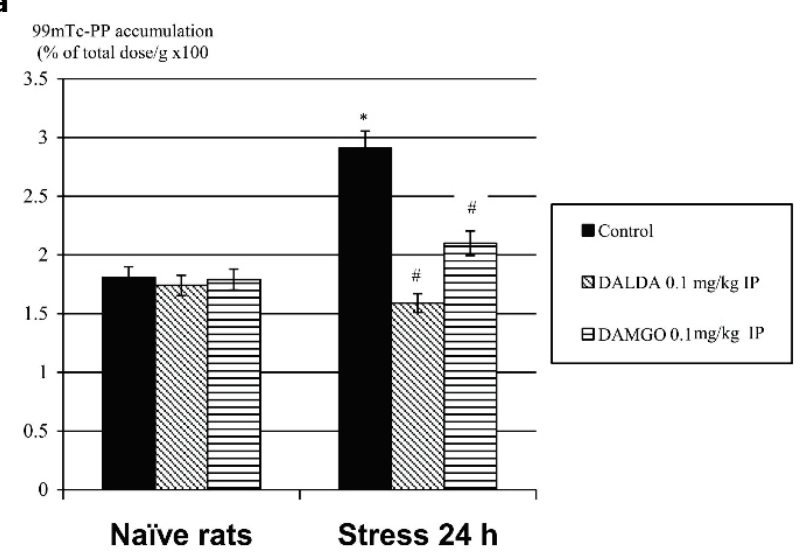

b

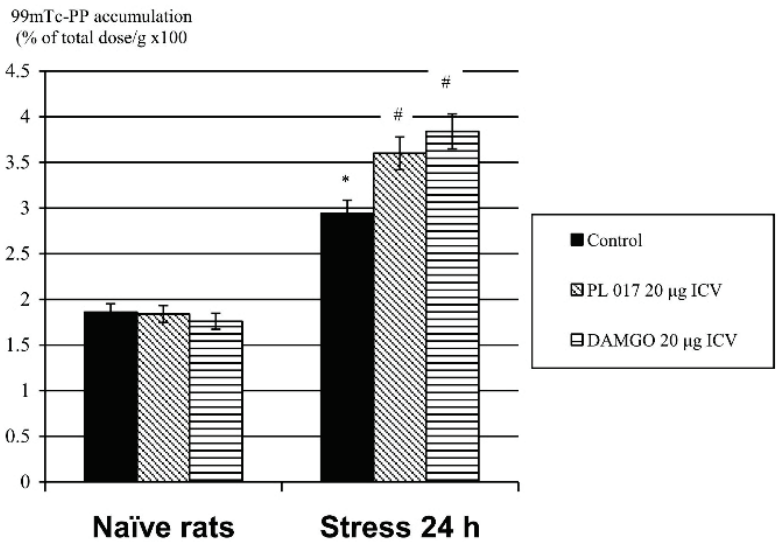

Fig. 2. (a) Effect of the intraperitoneal administration of 2 peptide $\mu$ opioid receptor agonists on the immobilization stress induced myocardial injury measured by the level of accumulation of ${ }^{99 m} \mathrm{Tc}$ pyrophosphate. ${ }^{*}$ Significant difference in comparison with naïve animals. " Significant differences compared to control stress. (b). Effect of the intracerebroventricular administration of 2 peptide $\mu$ opioid receptor agonists on the immobilization stress induced myocardial injury measured by the level of accumulation of ${ }^{99 \mathrm{~m} T c}$ pyrophosphate. ${ }^{*}$ Significant difference in comparison with naïve animals. " Significant differences compared to control stress. 


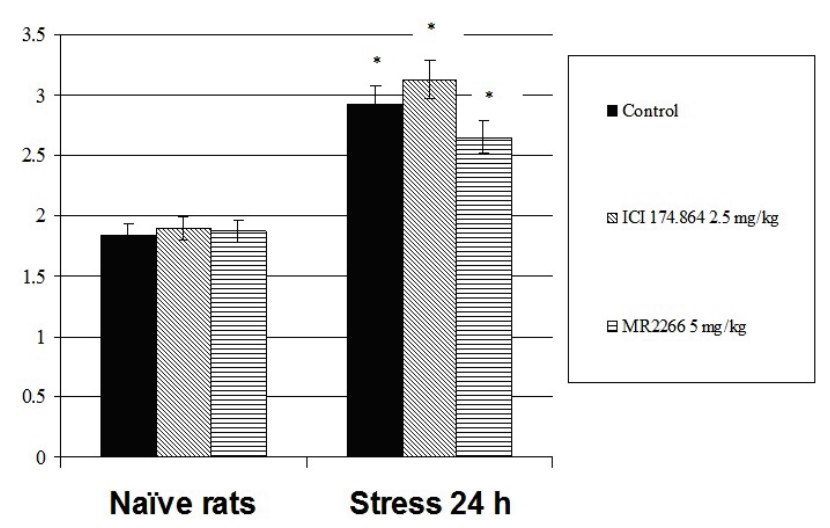

Fig. 3. Effect of administration of $\delta$ and $\kappa$ opioid receptor antagonists on the immobilization stress induced myocardial injury measured by the level of accumulation of ${ }^{99 m} \mathrm{Tc}$ pyrophosphate. * Significant difference in comparison with naïve animals.

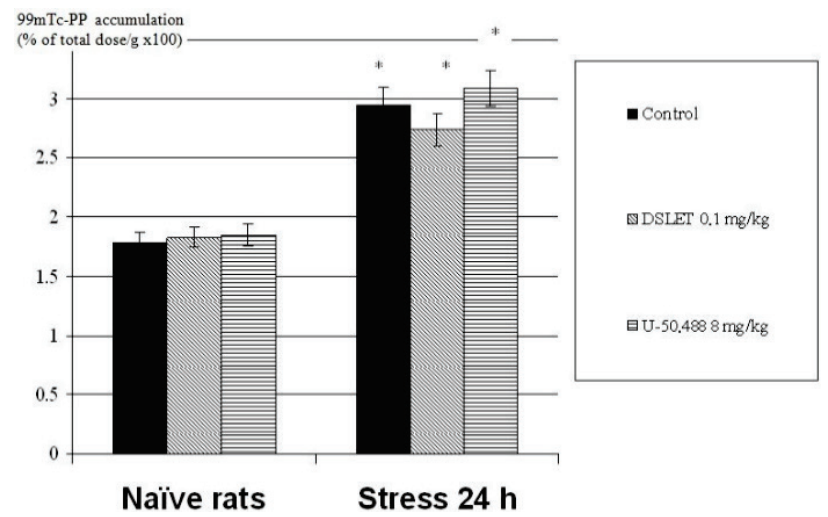

Fig. 4. Effect of administration of selective $\delta$ and $k$ opioid receptor agonists on the immobilization stress induced of myocardial injury measured by the level of accumulation of ${ }^{99 \mathrm{~m}} \mathrm{Tc}$ pyrophosphate. ${ }^{*}$ Significant difference in comparison with naïve animals.

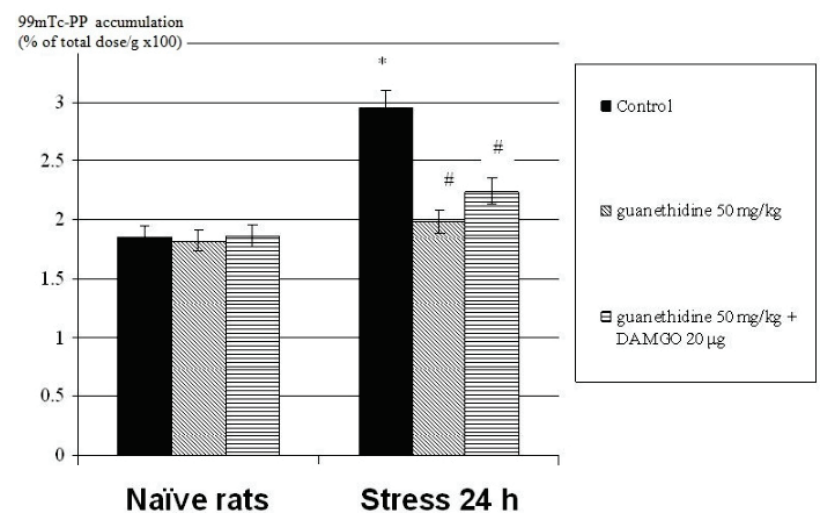

Fig. 5. Effect of subcutaneous administration of guanethidine and intracerebroventricular administration of DAMGO on the immobilization stress induced myocardial injury measured by the level of accumulation of ${ }^{99 \mathrm{~m}} \mathrm{Tc}$ pyrophosphate. * Significant difference in comparison with naïve animals. "Significant differences compared to control stress.

\section{Discussion}

Our results indicate that the immobilization stress causes damage to the heart. Our data are consistent with the results of other investigators (Miller and Mallov 1977) who also observed an enhancement of ${ }^{99 m}$ Tc-PP accumulation in the myocardium of food-shock stressed rats. Pretreatment with guanethidine prevented the stressinduced ${ }^{99 \mathrm{~m}}$ Tc-PP uptake by the heart of the stressed rats that indicated the involvement of endogenous catecholamines in the pathogenesis of SIC. In addition, these data indicate that our rat model of SIC is similar to TS because endogenous catecholamines are involved in the appearance of both immobilization induced cardiomyopathy and also TS (Riester et al. 2015, Smeijers et al. 2015, Sharkey et al. 2015, Nunez-Gil et al. 2015).

We found that administration of NxMB, which does not penetrate into the brain from the bloodstream, aggravated SIC. On the other hand, naltrexone, which crosses the BBB, prevented the emergence of SIC. These data indicated that endogenous agonists of central ORs are involved in the pathogenesis of SIC. The endogenous agonists of peripheral ORs prevented the occurrence of SIC. Endogenous agonists $\kappa$ and $\delta$ OR perhaps are not involved in the development of this cardiomyopathy, since antagonists and agonists of these ORs had no effect on the stress induced ${ }^{99 \mathrm{~m}} \mathrm{Tc}-\mathrm{PP}$ accumulation in the myocardium. It is well known that naltrexone and $\mathrm{NxMB}$ exhibit a high affinity for $\mu \mathrm{OR}$. Therefore, it can be hypothesized that central and peripheral $\mu$ ORs are involved in the regulation of cardiac tolerance to stress but their role in regulating the cardiac tolerance to stress is different. Activation of the central $\mu \mathrm{OR}$ aggravates the pathologic effect of stress and a stimulation of the peripheral $\mu$ OR has a cardioprotective effect. Therefore, NxMB exacerbates the pathogenic effect of stress. Naltrexone blocks both central and peripheral $\mu$ ORs thereby excluding their involvement in the regulation of cardiac tolerance to impact of stress.

We decided to test this hypothesis using the selective $\mu$ OR agonist DALDA, which cannot cross the BBB (Samii et al. 1994), and DAMGO, which exhibits antinociceptive effect (hot-plate test in mice) at a dose of $2.5 \mathrm{mg} / \mathrm{kg}$ probably due to the stimulation of central $\mu \mathrm{OR}$. The antinociceptive effect in hot-plate test indirectly indicates stimulation of the central opioid receptors (Delay-Goyet et al. 1991). This opioid did not exhibit antinociceptive effect at a dose of $1.25 \mathrm{mg} / \mathrm{kg}$ in 
this test (Delay-Goyet et al. 1991). We used DAMGO at a dose of $0.1 \mathrm{mg} / \mathrm{kg}$ to avoid activation of central OR. Both opioid peptides exhibit similar affinity to $\mu \mathrm{OR}$ (Schiller et al. 1989). The single most important difference between these opioids is the permeability to the BBB. We found that DALDA showed a strong cardioprotective effect in the stressed rats, while the cardioprotective effect of DAMGO was weaker, probably because small quantities of DAMGO can cross the BBB, and partially occupy central $\mu \mathrm{OR}$. These results are in agreement with our previously published data (Lishmanov et al. 2017).

In further experiments, we explored whether the activation of the central $\mu \mathrm{OR}$ would affect the heart resistance to stress. It turned out that intracerebroventricular administration of DAMGO, or the selective $\mu$ OR agonist PL017 aggravated the stress-induced injury to the heart. Pretreatment with guanethidine completely eliminated the negative effect of intracerebroventricular DAMGO administration. This result suggested an involvement of the sympathetic nervous system (SNS) in the mediation of stress-induced myocardial injury, and our hypothesis is in agreement with data of other investigators (Hassen and Feuerstein 1987, Kiritsy-Roy et al. 1989, Yamauchi et al. 1997) and our previously published data (Lishmanov et al. 2017).

In 1987, Hassen and Feuerstein found that the stimulation of $\mu \mathrm{OR}$ in $\mathrm{n}$. tractus solitarius leads to activation of the SNS. In 1989, Kiritsy-Roy et al. experiments with awake rats showed that intracerebroventricular administration of selective $\mu \mathrm{OR}$ agonist DAMGO or $\delta$ OR agonist DPDPE leads to a 2 to 3 fold increase in the plasma level of norepinephrine, and increase in plasma epinephrine concentration by several ten folds. Maximum stimulation of SNS was achieved with the administration of $5 \mathrm{nM}$ of DAMGO and $125 \mathrm{nM}$ of DPDPE, with the latter compound having no effect on catecholamine levels when administered at a dose of $5 \mathrm{nM}$ (Kiritsy-Roy et al. 1989). In 1997, Yamauchi et al. found that the intracerebroventricular administration of $\beta$-endorphin (preferential $\mu$ and $\delta$ OR agonist $\mathrm{R}$ ) causes an increase in blood plasma epinephrine and norepinephrine levels in rats. Naloxone $(2 \mathrm{mg} / \mathrm{kg}$ intravenously) completely eliminated this effect of $\beta$-endorphin. These data demonstrate that occupancy of central $\mu \mathrm{OR}$ by agonists can promote an activation of SNS. In contrast there are data that demonstrate following occupancy of peripheral $\mu \mathrm{OR}$ by agonists results in a limitation of norepinephrine release from sympathetic nerve terminals in the heart (Ledda et al. 1982, Ensinger et al. 1984, Von Kugelgen et al. 1985, Fuder et al. 1986, Szabo et al. 1986), and epinephrine release from the adrenal glands is observed (Chen et al. 1989). However, most publications indicate that the limitation of norepinephrine release from peripheral sympathetic terminals is a result of presynaptic $\delta$ and $\kappa$ OR activation (Von Kugelgen et al. 1985, Fuder et al. 1986, Szabo et al. 1986), and thus it is unclear why these receptor agonists (DSLET and U-50,488) had no effect on SIC. Furthermore, it was found that $\kappa$ OR agonists can inhibit synthesis of catecholamines in chromaffin cells (Takekoshi et al. 2000). Opioid receptors have been found in chromaffin cells (Saiani et al. 1982, Abood et al. 1995, Kampa et al. 1999) primarily consisting of $\delta$ (Abood et al. 1995) or к OR (Kampa et al. 1999). Kampa et al. (1999) demonstrated that human pheochromocytoma cells contain $\kappa_{1} \mathrm{OR}$, fewer $\kappa_{2} \mathrm{OR}$ and minimal binding capacity for $\delta$ and $\mu$ OR agonists sites. It remains unclear why exactly the activation of peripheral $\mu$ opioid receptors increased cardiac tolerance to stress. In conclusion, it should be noted that in the regulation of heart tolerance to the impact of ischemia and reperfusion an important role is played by $\mu, \delta, \kappa$ ORs (Abood et al. 1995), and in regulation of cardiac tolerance to the stress only $\mu$ OR are involved according to our data. The reason for such differences in the functional role of ORs remains unclear.

\section{Conclusions}

Naltrexone enhanced the cardiac tolerance to the immobilization stress. Naltrexone methyl bromide aggravated stress-induced cardiomyopathy. The selective $\mu$ OR agonist DALDA, which does not cross the BBB, completely prevented stress-induced heart injury. The selective $\mu$ OR agonist DAMGO, which is capable of crossing the BBB, exhibited weaker effect than DALDA. The selective $\delta$ and $\kappa$ OR ligands did not alter the stress induced ${ }^{99 \mathrm{~m}} \mathrm{Tc}$-pyrophosphate accumulation in the heart. Intracerebroventricular administration of the selective $\mu$ OR agonists aggravated the stress-induced heart injury. Pretreatment with guanethidine abolished the noxious effects of the immobilization stress. Guanethidine administered alone exhibited cardioprotective properties. Thus, stimulation of central $\mu \mathrm{OR}$ mediates the emergence of stress cardiomyopathy. In contrast, stimulation of peripheral $\mu$ OR contributes to an increase in cardiac tolerance to stress. Overall, these results 
support our hypothesis that opioid-mediated cardioprotection is mediated via peripheral $\mu \mathrm{OR}$ activation.

\section{Conflict of Interest}

There is no conflict of interest.

\section{Acknowledgements}

The authors are grateful to Dr. Kevin Gormley (Division of Neuroscience \& Behavioral Research, NIDA NIH, Bethesda, USA) for providing the peptides (DAMGO,
DSLET, ICI 174.864, PL017). The authors are grateful to Professor P. W. Schiller (Clinical Research Institute of Montreal, Montreal, Quebec, Canada) for kindly granting DALDA. The authors are grateful to Drs. P Veerhoff and Dr. Duttmann (Boehringer Ingelheim KG, Ingelheim am Rhein, Germany) who kindly donated the naltrexone methyl bromide and MR2266. This study was funded by Russian Science Foundation (grant 18-75-00001). The section dedicated to naltrexone is framed within the framework of state. assignments AAAA-A15115120910024-0.

\section{References}

ABOOD ME, TAO Q: Characterization of a delta opioid receptor in rat pheochromocytoma cells. $J$ Pharmacol Exp Ther 274: 1566-1573, 1995.

AGRAWAL S, SHIRANI J, GARG L, SINGH A, LONGO S, LONGO A, FEGLEY M, STONE L, RAZAVI M, RADOIANU N, NANDA S: Pheochromocytoma and stress cardiomyopathy: Insight into pathogenesis. World J Cardiol 9: 255-260, 2017.

AKASHI YJ, NAKAZAWA K, SAKAKIBARA M, MIYAKE F, KOIKE H, SASAKA K: The clinical features of takotsubo cardiomyopathy. QJM 96: 563-573, 2003.

BELLIVEAU D, DE S: Reverse takotsubo cardiomyopathy following exogenous epinephrine administration in the early postpartum period. Echocardiography 33: 1089-1091, 2016.

BROWEN DR, ROBERTSON MJ, GOLDBERG LI: Reversal of morphine-induced catalepsy in the rat by narcotic antagonists and their quaternary derivatives. Neuropharmacology 22: 317-321, 1983.

BRUNETTI ND, SANTORO F, DE GENNARO L, CORREALE M, GAGLIONE A, Di BIASE M: Drug treatment rates with beta-blockers and ACE-inhibitors/angiotensin receptor blockers and recurrences in takotsubo cardiomyopathy: A meta-regression analysis. Int J Cardiol 214: 340-342, 2016.

CASEY RT, CHALLIS BG, PITFIELD D, MAHROOF RM, JAMIESON N, BHAGRA CJ, VUYLSTEKE A, PETTIT SJ, CHATTERJEE KC: Management of an acute catecholamine-induced cardiomyopathy and circulatory collapse: a multidisciplinary approach. Endocrinol Diabetes Metab Case Rep 2017: pii: 17-0122, 2017.

CECCACCI A, MANCONE M, CALCAGNO S, DE VINCENTIS G, SARDELLA G, FEDELE F: Role of MIBG scintigraphy in reverse Tako-tsubo cardiomyopathy: Confirming a pathophysiologic hypothesis. Int J Cardiol 223: 54-55, 2016.

CHANG KJ, WEI E, KILLIAN A, CHANG JK: Potent morphiceptin analogs: structure activity relationships and morphine-like activities. J Pharmacol Exp Ther 227: 403-408, 1983.

CHEN W, DILSIZIAN V: Cardiac sympathetic disturbance in takotsubo cardiomyopathy: primary etiology or a compensatory response to heart failure? JACC Cardiovasc Imaging 9: 991-993, 2016.

CHEN W, DILSIZIAN V: Exploring the pathophysiology of takotsubo cardiomyopathy. Curr Cardiol Rep 19: 53, 2017.

CHEN YM, DIXON WR, WAKADE AR: The effect of etorphine on the secretion of endogenous catecholamines and total tritium evoked by nerve- and acetylcholine-stimulation in perfused rat adrenal glands. Life Sci 44: 167-174, 1989.

CHRISTENSEN TE, BANG LE, HOLMVANG L, SKOVGAARD DC, OTURAI DB, SØHOLM H, THOMSEN JH, ANDERSSON HB, GHOTBI AA, IHLEMANN N, KJAER A, HASBAK P: ${ }^{123}$ I-MIBG scintigraphy in the subacute state of takotsubo cardiomyopathy. JACC Cardiovasc Imaging 9: 982-990, 2016.

CRABTREE BL: Review of naltrexone, a long-acting opiate antagonist. Clin Pharm 3: 273-280, 1984. 
DAUGE V, ROSSIGNOL P, ROQUES BP: Comparison of the behavioural effects induced by administration in rat nucleus accumbens or nucleus caudatus of selective $\mu$ and $\delta$ opioid peptides or kelatorphan an inhibitor of enkephalin-degrading-enzymes. Psychopharmacology (Berl) 96: 343-352, 1988.

DELAY-GOYET P, RUIZ-GAYO M, BAAMONDE A, GACEL G, MORGAT JL, ROQUES BP: Brain passage of BUBU, a highly selective and potent agonist for delta opioid receptors: in vivo binding and mu versus delta receptors occupancy. Pharmacol Biochem Behav 38: 155-162, 1991.

EL-BATTRAWY I, LANG S, ANSARI U, SATTLER K, BEHNES M, SCHRAMM K, FASTNER C, TÜLÜMEN E, ZHOU $\mathrm{X}$, HOFFMANN U, BORGGREFE M, AKIN I: Incidence and prognostic relevance of cardiopulmonary failure in takotsubo cardiomyopathy. Sci Rep 7: 14673, 2017.

ELIKOWSKI W, MAŁEK-ELIKOWSKA M, KAROŃ J, MROZIŃSKA M, BASZKO A, HORBACKA K: Takotsubo cardiomyopathy after intravenous epinephrine administration following cardiac arrest provoked by pneumoperitoneum - a case report. Pol Merkur Lekarski 42: 165-169, 2017.

ENSINGER H, HEDLER L, SCHURR C, STARKE K: Ethylketocyclazocine decreases noradrenaline release and blood pressure in the rabbit at a peripheral opioid receptor. Naunyn Schmiedebergs Arch Pharmacol 328: 20-23, 1984.

FUDER H, BUDER M, RIERS HD, ROTHACHER G: On the opioid receptor subtype inhibiting the evoked release of ${ }^{3}$ H-noradrenaline from guinea-pig atria in vitro. Naunyn Schmiedebergs Arch Pharmacol 332: 148-155, 1986.

HASSEN AN, FEUERSTEIN G: $\mu$-Opioid receptors in NTS elicit pressor responses via sympathetic pathways. Am J Physiol 252: H156-H162, 1987.

JOHANSSON G, JONSSON L, LANNEK N, BLOMGREN L, LINDBERG P, POUPA O: Severe stress-cardiopathy in pigs. Am Heart $J$ 87: 451-457, 1974.

JÖNSSON L, JOHANSSON G, LANNEK N, LINDBERG P, POUPA O: Histochemical and electron microscopic studies of acute cardiomyopathy induced by restraint stress in pigs. Recent Adv Stud Cardiac Struct Metab 6: 461-470, 1975.

KAMPA M, MARGIORIS AN, HATZOGLOU A, DERMITZAKI I, DENIZOT A, HENRY JF: $\kappa_{1}$-Opioid binding sites are the dominant opioid binding sites in surgical specimens of human pheochromocytomas and in a human pheochromocytoma (KAT45) cell line. Eur J Pharmacol 364: 255-262, 1999.

KHERA R, LIGHT-MCGROARY K, ZAHR F, HORWITZ PA, GIROTRA S: Trends in hospitalization for takotsubo cardiomyopathy in the United States. Am Heart J 172: 53-63, 2016.

KIDO K, GUGLIN M: Drug-induced takotsubo cardiomyopathy. J Cardiovasc Pharmacol Ther 22: 552-563, 2017.

KIRITSY-ROY JA, MARSON L, VAN LOON GR: Sympathoadrenal, cardiovascular and blood gas responses to highly selective mu and delta opioid peptides. J Pharmacol Exp Ther 251: 1096-1103, 1989.

KURISU S, SATO H, KAWAGOE T, ISHIHARA M, SHIMATANI Y, NISHIOKA K: Tako-tsubo-like left ventricular dysfunction with ST-segment elevation: a novel cardiac syndrome mimicking acute myocardial infarction. Am Heart J 143: 448-455, 2002.

LAHTI RA, MICKELSON MM, MCCALL JM, VON VOIGTLANDER PF: $\left[{ }^{3}\right.$ H]U-69593 a highly selective ligand for the opioid $\kappa$ receptor. Eur J Pharmacol 109: 281-284, 1985.

LEDDA F, MANTELLI L: Possible presynaptic inhibitory effect of etorphine on synaptic nerve terminals of guinea-pig heart. Eur J Endocrinol 85: 247-250, 1982.

LISHMANOV YB, MASLOV LN, NARYZHNAYA NV: Cardioprotective effects of stimulation of peripheral $\mu$-opiate receptors and the role of opiatergic mechanisms in the pathogenesis of stress-induced heart damage. Bull Exp Biol Med 123: 239-241, 1997.

LISHMANOV YB, MASLOV LN, UGDYZHEKOVA DS: Participation of central and peripheral $\kappa_{1}$ and $\kappa_{2}$ opioid receptors in arrhythmogenesis. Clin Exp Pharmacol Physiol 26: 716-723, 1999.

LISHMANOV YB, TSIBUL'NIKOV SY, NARYZHNAYA NV, KOROBOV MV, MASLOV LN: The role of endogenous opioid system in the regulation of heart tolerance to stress-induced damage. Bull Exp Biol Med 163: 25-27, 2017.

MAITRE L, STAEHELIN M: Guanethidine uptake and noradrenaline depletion in noradrenaline storage particles of the rat heart. Biochem Pharmacol 20: 1233-1242, 1971. 
MASLOV LN, LISHMANOV YB, OELTGEN PR, BARZAKH EI, KRYLATOV AV, GOVINDASWAMI M: Activation of peripheral $\delta_{2}$ opioid receptors increases cardiac tolerance to ischemia/reperfusion injury: Involvement of protein kinase $\mathrm{C}$, NO-synthase, $\mathrm{K}_{\mathrm{ATP}}$ channels and the autonomic nervous system. Life Sci 84: 657-663, 2009.

MASLOV LN, KRYLATOV AV, NARYZHAIA NV, SOLENKOVA NV, LISHMANOV AIU, BOGOMAZ SA, GROSS GJ, STEFANO JB, LOKTIUSHINA BA: Interactions of peripheral mu-opioid receptors and $\mathrm{K}_{\mathrm{ATP}}$-channels in regulation of cardiac electrical stability in ischemia, reperfusion, and postinfarction cardiosclerosis. Ross Fiziol Zh Im I M Sechenova 88: 842-850, 2002.

MILLER DG, MALLOV S: Quantitative determination of stress-induced myocardial damage in rats. Pharmacol Biochem Behav 7: 139-145, 1977.

MISRA AL, PONTANI RB, VADLAMANI NL: Intravenous kinetics and metabolism of $\left[15,16-{ }^{3} \mathrm{H}\right]$ naltrexonium methiodide in the rat. $J$ Pharm Pharmacol 39: 225-227, 1987.

NAZIR S, LOHANI S, TACHAMO N, GHIMIRE S, POUDEL DR, DONATO A: Takotsubo cardiomyopath associated with epinephrine use: A systematic review and meta-analysis. Int J Cardiol 229: 67-70, 2017.

NUNEZ-GIL IJ, BERNARDO E, FELTES G, ESCANED J, MEJÍA-RENTERÍA HD, DE AGUSTÍN JA: Platelet function in Takotsubo cardiomyopathy. J Thromb Thrombolysis 39: 452-458, 2015.

ORAS J, REDFORS B, ALI A, ALKHOURY J, SEEMAN-LODDING H, OMEROVIC E, RICKSTEN SE: Early treatment with isoflurane attenuates left ventricular dysfunction and improves survival in experimental Takotsubo. Acta Anaesthesiol Scand 61: 399-407, 2017a.

ORAS J, REDFORS B, ALI A, LUNDGREN J, SIHLBOM C, THORSELL A, SEEMAN-LODDING H, OMEROVIC E, RICKSTEN SE: Anaesthetic-induced cardioprotection in an experimental model of the Takotsubo syndrome - isoflurane vs. propofol. Acta Anaesthesiol Scand 61: 309-321, $2017 \mathrm{~b}$.

PAVIN D, LE BRETON H, DAUBERT C: Human stress cardiomyopathy mimicking acute myocardial syndrome. Heart 78: 509-511, 1997.

PELLICCIA F, KASKI JC, CREA F, CAMICI PG: Pathophysiology of takotsubo syndrome. Circulation 135: 2426-2441, 2017.

REBROVA TY, MASLOV LN, LISHMANOV AY, TAM SV: Stimulation of mu and delta-opiate receptors and tolerance of isolated heart to oxidative stress: the role of NO-synthase. Biochemistry (Mosc) 66: 422-428, 2001.

RIESTER A, WEISMANN D, QUINKLER M, LICHTENAUER UD, SOMMEREY S, HALBRITTER R: Lifethreatening events in patients with pheochromocytoma. Eur J Endocrinol 173: 757-764, 2015.

ROQUES BP, GACEL G, DAUGE V, BAAMONDE A, CALENCO G, TURCAUD S: Novel approaches in the development of new analgesics. Neurophysiol Clin 20: 369-387, 1990.

SACHDEVA J, DAI W, KLONER RA: Functional and histological assessment of an experimental model of Takotsubo's cardiomyopathy. J Am Heart Assoc 3: e000921, 2014.

SAIANI L, GUIDOTTI A: Opiate receptor-mediated inhibition of catecholamine release in primary cultures of bovine adrenal chromaffin cells. J Neurochem 39: 1669-1676, 1982.

SAMII A, BICKEL U, STROTH U, PARDRIDGE WM: Blood-brain barrier transport of neuropeptides: analysis with a metabolically stable dermorphin analogue. Am J Physiol 267: E124-E131, 1994.

SATO H, TATEISHI H, UCHIDA T, ISHIHARA M, SHIMATANI Y, NISHIOKA K: Tako-tsubo-like left ventricular dysfunction due to multivessel coronary spasm. In: Clinical Aspect of Myocardial Injury: From Ischemia to Heart Failure. KODAMA K, HAZE K, HON M (eds), Tokyo: Kagakuyourosha, 1990, pp 56-64.

SCHILLER PW, NGUYEN TM-D, LEMIEUX C: Two new families of opioid peptide analogs displaying extraordinary $\mu$-receptor selectivity and preference for either peripheral or central sites. In: Advances in the Biosciences. London: Pergamon Press, 1989, pp 85-88.

SESTINI S, PESTELLI F, LEONCINI M, BELLANDI F, MAZZEO C, MANSI L, CARRIO I, CASTAGNOLI A: The natural history of takotsubo syndrome: a two-year follow-up study with myocardial sympathetic and perfusion G-SPECT imaging. Eur J Nucl Med Mol Imaging 44: 267-283, 2017. 
SHARKEY SW, MCALLISTER N, DASSENKO D, LIN D, HAN K, MARON BJ: Evidence that high catecholamine levels produced by pheochromocytoma may be responsible for tako-tsubo cardiomyopathy. Am J Cardiol 115 : 1615-1618, 2015.

SMEIJERS L, SZABÓ BM, VAN DAMMEN L, WONNINK W, JAKOBS BS, BOSCH JA: Emotional, neurohormonal, and hemodynamic responses to mental stress in Tako-Tsubo cardiomyopathy. Am J Cardiol 115: 1580-1586, 2015.

STIERMAIER T, MOELLER C, OEHLER K, DESCH S, GRAF T, EITEL C: Long-term excess mortality in takotsubo cardiomyopathy: predictors, causes and clinical consequences. Eur J Heart Fail 18: 650-656, 2016.

SZABO B, HEDLER L, ENSINGER H, STARKE K: Opioid peptides decrease noradrenaline release and blood pressure in the rabbit at peripheral receptors. Naunyn Schmiedebergs Arch Pharmacol 332: 50-56, 1986.

TAKEKOSHI K, ISHII K, KAWAKAMI Y, ISOBE K, NAKAI T: $\kappa$-Opioid inhibits catecholamine biosynthesis in PC12 rat pheochromocytoma cell. FEBS Lett 477: 273-277, 2000.

THOMAS JB, ZHENG X, MASCARELLA SW, ROTHMAN RB, DERSCH CM, PARTILLA JS: N-Substituted 9ß-methyl-5-(3-hydroxyphenyl)morphans are opioid receptor pure antagonists. J Med Chem 41: 4143-4149, 1998.

TSUCHIHASHI K, UESHIMA K, UCHIDA T, OH-MURA N, KIMURA K, OWA M: Transient left ventricular apical ballooning without coronary artery stenosis: a novel heart syndrome mimicking acute myocardial infarction: Angina Pectoris-Myocardial Infarction Investigations in Japan. J Am Coll Cardiol 38: 11-18, 2001.

UEYAMA T, KASAMATSU K, HANO T, YAMAMOTO K, TSURUO Y, NISHIO I: Emotional stress induces transient left ventricular hypocontraction in the rat via activation of cardiac adrenoceptors: a possible animal model of 'tako-tsubo' cardiomyopathy. Circ J 66: 712-713, 2002.

UEYAMA T: Emotional stress-induced Tako-tsubo cardiomyopathy: animal model and molecular mechanism. Ann $N Y$ Acad Sci 1018: 437-444, 2004.

VON KUGELGEN I, ILLESS P, WOLF D, STARKE K: Presynaptic inhibitory opioid $\kappa$ - and $\delta$-receptors in a branch of the rabbit ileocolic artery. Eur J Pharmacol 118: 97-103, 1985.

VON VOIGTLANDER PF, LEWIS RA: U-50,488, a selective kappa opioid agonist: comparison to other reputed kappa agonists. Prog Neuropsychopharmacol Biol Psychiatry 6: 467-470, 1982.

YAMAUCHI N, SHIBASAKI T, WAKABAYASHI I, DEMURA H: Brain $\beta$-endorphin and other opioids are involved in restraint stress-induced stimulation of the hypothalamic-pituitary-adrenal axis, the sympathetic nervous system, and the adrenal medulla in the rat. Brain Res 777: 140-146, 1997.

Y-HASSAN S: Clinical features and outcome of pheochromocytoma-induced takotsubo syndrome: analysis of 80 published cases. Am J Cardiol 117: 1836-1844, 2016.

ZHANG R, GUPTA D, ALBERT SG: Pheochromocytoma as a reversible cause of cardiomyopathy: Analysis and review of the literature. Int J Cardiol 249: 319-323, 2017. 